This is the accepted version of the following article:

Kurbanoglu S., Rivas L., Ozkan S.A., Merkoçi A..

Electrochemically reduced graphene and iridium oxide nanoparticles for inhibition-based angiotensin-converting enzyme inhibitor detection. Biosensors and Bioelectronics, (2017). 88. : 122 - . 10.1016/j.bios.2016.07.109,

which has been published in final form at https://dx.doi.org/10.1016/j.bios.2016.07.109 (c) https://dx.doi.org/10.1016/j.bios.2016.07.109. This manuscript version is made available under the CC-BY-NC-ND 4.0 license http://creativecommons.org/licenses/by-nc-nd/4.0/ 


\title{
ELECTROCHEMICALLY REDUCED GRAPHENE AND IRIDIUM OXIDE NANOPARTICLES FOR INHIBITION-BASED ANGIOTENSIN- CONVERTING ENZYME INHIBITOR DETECTION
}

\author{
Sevinc Kurbanoglu ${ }^{\mathrm{a}, \mathrm{b}}$, Lourdes Rivas ${ }^{\mathrm{a}}$, Sibel A. Ozkan ${ }^{\mathrm{b}}$, Arben Merkoçia,c*
}

${ }^{a}$ Nanobioelectronics \& Biosensors Group, Catalan Institute of Nanoscience and Nanotechnology (ICN2), CSIC and The Barcelona Institute of Science and Technology, Campus UAB, 08193, Bellaterra, Barcelona, Spain

${ }^{\mathrm{b}}$ Ankara University, Faculty of Pharmacy, Department of Analytical Chemistry, 06100, Tandogan, Ankara, Turkey

'ICREA, Pg. Lluís Companys 23, 08010 Barcelona, Spain.

* E-mail: arben.merkoci@icn2.cat 
ABSTRACT: In this work, a novel biosensor based on electrochemically reduced graphene oxide and iridium oxide nanoparticles for the detection of angiotensin-converting enzyme inhibitor drug, captopril, is presented. For the preparation of the biosensor, tyrosinase is immobilized onto screen printed electrode by using 1-Ethyl-3-(3-dimethylaminopropyl)carbodiimide and $\mathrm{N}-\mathrm{Hydroxysuccinimide} \mathrm{coupling} \mathrm{reagents,} \mathrm{in} \mathrm{electrochemically} \mathrm{reduced}$ graphene oxide and iridium oxide nanoparticles matrix. Biosensor response is characterized towards catechol, in terms of graphene oxide concentration, number of cycles to reduce graphene oxide, volume of iridium oxide nanoparticles and tyrosinase solution. The designed biosensor is used to inhibit tyrosinase activity by Captopril, which is generally used to treat congestive heart failure. It is an angiotensin-converting enzyme inhibitor that operates via chelating copper at the active site of tyrosinase and thioquinone formation. The captopril detections using both inhibition ways are very sensitive with low limits of detection: 0.019 $\mu \mathrm{M}$ and $0.008 \mu \mathrm{M}$ for chelating copper at the active site of tyrosinase and thioquinone formation, respectively. The proposed methods have been successfully applied in captopril determination in spiked human serum and pharmaceutical dosage forms with acceptable recovery values.

Keywords: Captopril detection, Electrochemically reduced graphene oxide, Enzyme inhibition, Iridium oxide nanoparticles, Angiotensin-converting enzyme inhibitor, Enzyme biosensors 


\section{INTRODUCTION}

Captopril (CAP, (2S)-1-[(2S)-2-methyl-3-sulfanylpropanoyl] pyrrolidine-2-carboxylic acid) is an angiotensin-converting enzyme inhibitor drug that belongs to antihypertensive agents. It is widely used to treat congestive heart failure in combination with other drugs (e.g. cardiac glycosides, diuretics, $\beta$-adrenergic blockers) and to treat hypertension and heart failure through its inhibitory effect on the angiotensin-converting enzyme. CAP was the first orally active antihypertensive inhibitor to be developed (Atkinson and Robertson, 1979; Patchett et al., 1980; Smith and Vane, 2003). Angiotensin-converting enzyme inhibitors are important in the renin-angiotensin system due to their control to the potent vasoconstrictor angiotensin II. Angiotensin-converting enzyme inhibitors can be classified according to their functional groups: carboxyl, sulfhydryl, or phosphinyl. These groups are responsible for differences in the pharmacokinetic and safety profiles of the drugs (Piepho, 2000; Mcareavey and Robertson, 1999; Song and White, 2002; Ehlers and Riordan, 1989).

Tyrosinase (Tyr), also known as phenol oxidase, catecholases, phenolase, catechol oxidase, or even polyphenol oxidase, is extensively found in nature (Okot-Kotber et al., 2002; VamosVigyazo and Haard, 1981). Tyr is a multifunctional copper-containing enzyme that catalyzes two distinct reactions of melanin synthesis: a hydroxylation of monophenols to $o$-diphenols (monophenolase activity) and an oxidation of o-diphenols to o-quinones (diphenolase activity), both using molecular oxygen (Espin et al., 1995). O-quinone is the product of catechol oxidation through Tyr catecholase activity that can be followed with amperometry.

CAP forms both a copper-captopril complex and a disulfide bond between captopril in cysteine-rich domains at the active site of tyrosinase (Cleland et al., 1984; Naish-Byfield et al., 1994; Espin and Wichers, 2001; Andujar-Sanchez et al., 2004; Kim and Uyama, 2005). The inhibition of both monophenolase and diphenolase activities of tyrosinase by captopril occurs due to both copper-captopril complex formation and disulphide interchange reaction 
between captopril and cysteine rich domains at the active site of the enzyme. The interaction between the enzymatic-generated product (o-quinone) and captopril shows a competitive inhibition (formation of copper-captopril complex results an irreversible inhibition) (AndujarSanchez et al., 2004; Kim and Uyama 2005; Chu et al., 2012).

In the literature, different analytical procedures have been developed for the determination of CAP such as electrochemical stripping voltammetry (Zargar et al., 2015), chemiluminescence (Liu and Li, 2015), spectrofluorimetry (Guo et al., 2015) and HPLC (Huang et al., 2006), flow injection analyses (Stefan et al., 2000). Enzymatic biosensors are generally used in drug detection through inhibition pathways. CAP is an irreversible non-competitive inhibitor and an irreversible competitive inhibitor of the monophenolase and diphenolase activities of mushroom tyrosinase. Using the inhibition percent of tyrosinase by CAP, CAP itself can be easily detected (Espin et al., 1995, Espin and Wichers, 2001).

Among electrochemical transducer modifiers, due to its high surface area, excellent conducting nature, wide potential windows, electrochemical inertness in catalyst, good electro-catalytic activity and high mechanical properties, graphene has been confirmed to be an excellent modifier and a promising candidate for immobilizing functional molecules in electrochemical applications (Shao et al., 2010; Reza et al., 2015; Kumar et al., 2015; Garg et al., 2015; Farid et al., 2016; Novoselov et al. 2004; Baptista-Pires et al. 2014; Rabti et al., 2016). Graphene oxide (GO), represents graphene with oxygen-containing functionalities in both sides of its layers (Shao et al., 2010). Since it can be accepted that these oxygen sides can increase the electron transfer rate, they can also destroy the $\pi$-electron cloud, leading to decrease in conductivity and carrier mobility (Gan and Hu, 2011; Davies et al., 2005). In order to solve this problem, graphene oxide is reduced to reduced graphene physically or chemically (Zhao et al., 2010; Dong et al., 2011). There are different ways to reduce graphene; a simple way is to prepare electrochemically reduced graphene (ERGO) since 
graphene can be reduced in cathodic potentials (Yun et al., 2015; Yang et al., 2014; Zhang et al., 2014; Zhang et al., 2014; Han et al., 2014; Gómez-Navarro et al., 2007). The electrochemically reduced graphene has large number of electroactive sites and its structure is similar with graphene (Li et al., 2015). These properties make ERGO a unique candidate for using in electrochemical biosensing applications (Yun et al., 2015; Yang et al., 2014; Han et al., 2014).

In recent studies, great attention has paid metallic oxide nanostructured materials due to their high conductivity, stability and catalytic properties (Tolosa et al.2013; Mayorga-Martinez et al., 2008). In our previous study, it was suggested that iridium oxide nanoparticles (IrOxNPs) along with magnetic nanoparticles can be in a very efficient mode used in antithyroid drug detection (Kurbanoglu et al., 2015).

In this study, we go further and show now a novel biosensing platform, with improved conductivity, using ERGO/IrOxNPs/Tyr for CAP biosensing, based on inhibition of Tyr through chelating copper at the active site and thioquinone formation. All the parameters affecting the biosensing such as enzyme amount, IrOxNPs volume, ERGO thickness and the incubation time were optimized. Afterwards, analytical characterization of the catechol biosensing and CAP detection were performed via Tyr inhibition using both methods. The fully validated inhibition methods have been applied to spiked human serum and pharmaceutical dosage forms containing CAP. Both systems present high analytical performance in terms of linear range and limit of detection.

\section{EXPERIMENTAL}

\subsection{Reagents}

Tyrosinase from mushroom ( $\geq 1000$ unit/mg), catechol and captopril were purchased from Sigma-Aldrich (St. Louis, MO). Potassium hexachloroiridate-(IV), sodium hydrogencitrate, graphene oxide (4 $\mathrm{mg} / \mathrm{mL}$, dispersion in $\mathrm{H}_{2} \mathrm{O}$ ), (1-Ethyl-3-(3-dimethylaminopropyl)- 
carbodiimide) (EDC), N-hydroxysuccinimide (NHS), ascorbic acid, uric acid and paracetamol were also purchased from Sigma-Aldrich (St. Louis, MO). Milli-Q water was obtained from purification system and all solutions were prepared with ultra-pure water from a MilliporeMilli-Q system. Human serum from human male AB plasma was purchased from SigmaAldrich (therefore, no need for ethical committee permission, St. Louis, MO). The inks for screen printed electrode preparation were purchased from Acheson Industries, Germany.

\subsection{Instrument and measurement}

For scanning electron-microscopy (SEM) images; samples were covered with gold solution using AMITECH K 550X and SEM images were obtained using ZEISS EVO 40 (Merlin, Carl Zeiss). For electrochemical measurements screen printed electrodes (SPEs) including a set of three electrodes: carbon working electrode with a diameter of $3 \mathrm{~mm}, \mathrm{Ag} / \mathrm{AgCl}$ pseudo reference electrode (with a potential of $10 \mathrm{mV}$ with respect to a commercial $\mathrm{Ag} / \mathrm{AgCl}$ electrode) and carbon counter electrode with an approximate thickness of $4 \mu \mathrm{m}$ were used. A screen-printing machine (DEK 248, DEK International, Switzerland) was used for sequential deposition of a graphite ink (Electrodag 423SS), $\mathrm{Ag} / \mathrm{AgCl}$ ink and insulating ink on a polyester substrate, respectively cured at $120{ }^{\circ} \mathrm{C}$ for $40 \mathrm{~min}$. Electrochemical experiments were performed using an electrochemical analyzer Autolab 20 (Eco-Chemie, The Netherlands) and a homemade connector was used for coupling SPEs and Autolab. Amperometric measurements were conducted at $-200 \mathrm{mV}$. Cyclic voltammograms (CVs) were recovered the potential range of -800 to $+800 \mathrm{mV}$ with scan rate of $50 \mathrm{mV} / \mathrm{s}$. All electrochemical experiments were carried out at room temperature using $0.1 \mathrm{M}$ phosphate buffer with $0.1 \mathrm{M} \mathrm{KCl}$ at $\mathrm{pH} 6.5$.

\subsection{Synthesis of iridium oxide nanoparticles}


Iridium oxide nanoparticles were synthesized from $2.6 \times 10^{-5} \mathrm{M}$ potassium hexachloroiridate(IV) solution and $1.6 \times 10^{-2} \mathrm{M}$ sodium hydrogencitrate solution. The solution of potassium hexachloroiridate-(IV) and sodium hydrogencitrate (pH 7.5) was refluxed in an oil bath with constant stirring for $30 \mathrm{~min}$. The $\mathrm{pH}$ of the solution was controlled and adjusted to $\mathrm{pH} 7.5$ with a reflux for 30 min until a constant $\mathrm{pH}$ reached. After refluxing this solution for $2 \mathrm{~h}$ under oxygen bubbling, a deep blue solution of IrOxNPs was obtained. The solution was stocked in a glass-stopper flask at $4{ }^{\circ} \mathrm{C}$ when not in use (Kuwabara et al., 2008).

\subsection{Preparation of ERGO/ IrOxNPs/ Tyr biocomposite}

ERGO was obtained by electrochemical procedure. $0.1 \%$ Graphene oxide was dropped on the surface of the screen printed electrode and continuous 15 cyclic voltammograms between 0 and $-1.4 \mathrm{~V}$ were obtained in $50 \mu \mathrm{L}, 0.1 \mathrm{M}$ phosphate buffer at $\mathrm{pH}$ 6.5. Afterwards $5 \mu \mathrm{L}$ IrOxNPs suspension was dropped on the surface of the screen printed electrode with $5 \mu \mathrm{L}$ of Tyr (115.42 Units $/ \mathrm{mL})$ including $6 \mathrm{mM}$ EDC and $10 \mathrm{mM}$ NHS. This electrode (ERGO/IrOxNPs/Tyr) incubated at $4{ }^{\circ} \mathrm{C}$ for $24 \mathrm{~h}$.

\subsection{CAP detection from its pharmaceutical dosage forms and spiked human}

\section{serum}

For detecting CAP from pharmaceutical dosage forms, 10 Kaptopril ${ }^{\circledR}$ film-coated tablets containing $25 \mathrm{mg}$ CAP were accurately weighed, crushed, powdered and a quantity equivalent to one tablet content was accurately weighted. It was diluted with phosphate buffer (PB), sonicated during 10 min and filtered. A final solution was obtained with dilution using PB. For human serum (human male $\mathrm{AB}$ plasma) analyzes recovery tests were performed. Known amounts of pure drug was added to the human serum plasma and diluted with PB.

\section{RESULTS AND DISCUSSION}

\subsection{Morphological studies}


The morphology of each component used in the biocomposite was followed by SEM images using backscatter electrons mode. Figure 1A shows SEM image of ERGO with IrOxNPs and Figure 1B the bioconjugate formed between the ERGO/IrOxNPs/Tyr. In Figure $1 \mathrm{~A} \& \mathrm{~B}$ it is possible to observe the IrOxNPs as bright dots and the immobilized Tyr can be seen from the cauliflower like structure of the SEM images from figure 1B. ERGO/IrOxNPs matrix is highly useful in preserving large electroactive area on the electrode surface and it forms suitable immobilization matrix for Tyr, as Tyr can be seen from the cauliflower structure. IrOxNPs were characterized in our previous studies (Kurbanoglu et al., 2015; MayorgaMartinez et al., 2014; Rivas et al., 2014). In figure 2, schematic representation of proposed detection system is given, displaying the tyrosinase (Tyr), ERGO and IrOxNPs including reaction involved in the catechol detection. As seen from figure 2, catechol can undergo electrochemical redox reaction with formation of $o$-quinone. This is a cycle reaction: catechol to $o$-quinone and $o$-quinone to catechol including two-electron process in $0.1 \mathrm{M}$ phosphate buffer at pH 6.5 with $0.1 \mathrm{M} \mathrm{KCl}$ (Papouchado et al.; 1972, Papouchado et al.; 1968, Rayn et al.; 1980). $O$-quinone is the product of catechol oxidation through Tyr catecholase activity that can be followed with amperometry. 


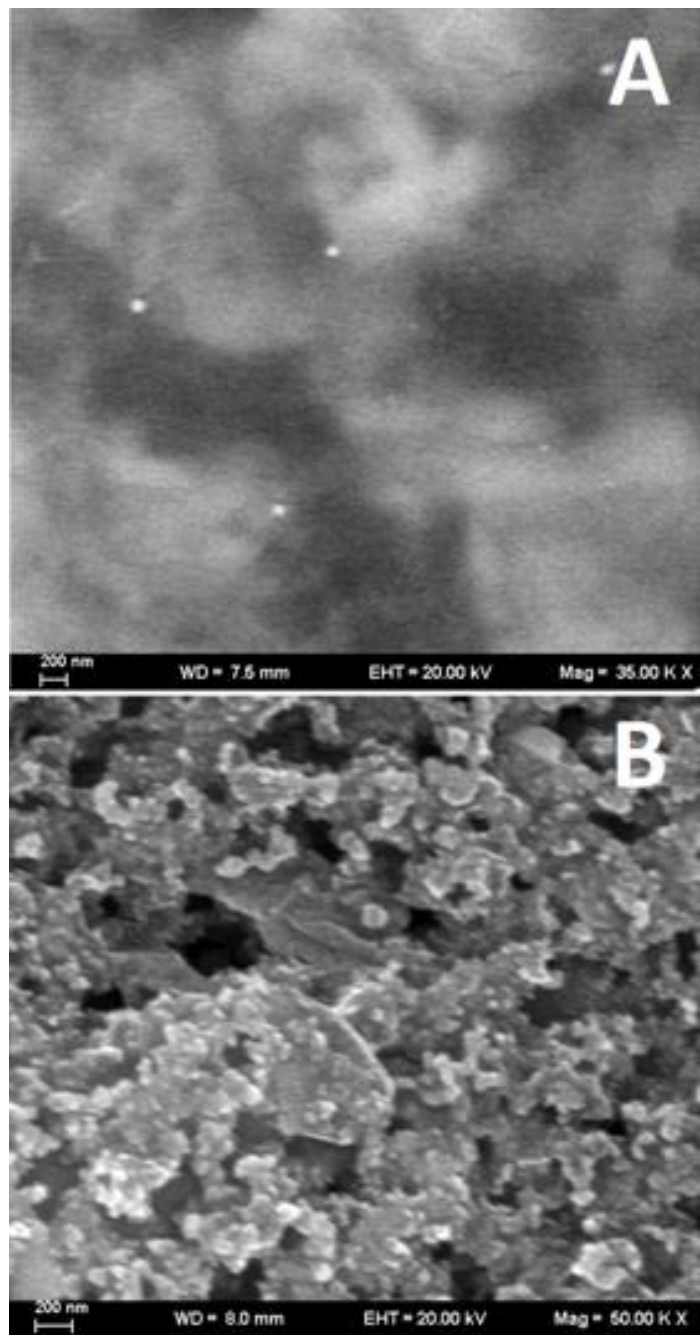

Figure 1. SEM images of (A) SPE/ERGO/IrOx (B) SPE/ERGO/IrOxNPs/Tyr Scale bars of SEM images are $200 \mathrm{~nm}$. The SEM images were obtained using backscatter electrons mode.

$$
\mathbf{H}_{2} \mathbf{O}
$$

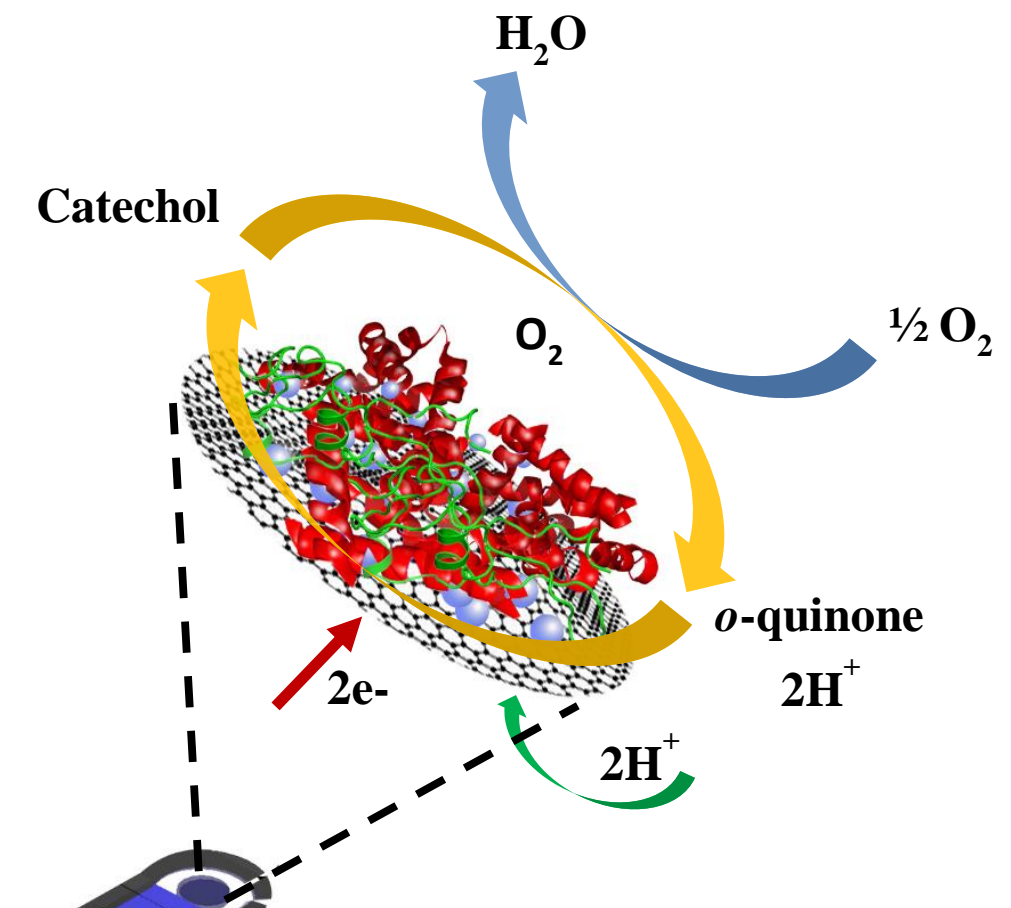

$$
\begin{aligned}
& \text { Catechol } \stackrel{\text { Tyr }}{\longrightarrow} \text { o-quinone }+\mathrm{H}_{2} \mathrm{O} \\
& \text { o-quinone }+2 \mathrm{H}^{+}+2 \mathrm{e}^{-} \longrightarrow \text { Catechol }
\end{aligned}
$$


Figure 2. Schematic representation of proposed detection system

194

\subsection{Optimization of the biosensing response towards catechol}

In order to immobilize Tyr, EDC/NHS chemistry was used. EDC (1-Ethyl-3-(3dimethylaminopropyl)-carbodiimide) is a zero-length crosslinking agent used generally to couple carboxyl or phosphate groups to primary amines. Since EDC is water soluble direct bioconjugation of EDC can be achieved. N-hydroxysuccinimide (NHS) is generally used to increase the stability of this active ester EDC. All parameters should be controlled when using EDC and NHS so that NPs do not aggregate due to loss of electrostatic repulsive forces among NPs, and the ratio EDC/NHS (Conde et al., 2012, Sanz et al., 2012, Conde et al. 2012). $6 \mathrm{mM}$ EDC and $10 \mathrm{mM}$ NHS was used to immobilize Tyr in this study.

Electrochemically reduced graphene was obtained by applying cyclic voltammetry to the graphene oxide starting from 0 to $-1.4 \mathrm{~V}$. Decreasing in the area of the CVs proves the formation of ERGO (Figure 3). 


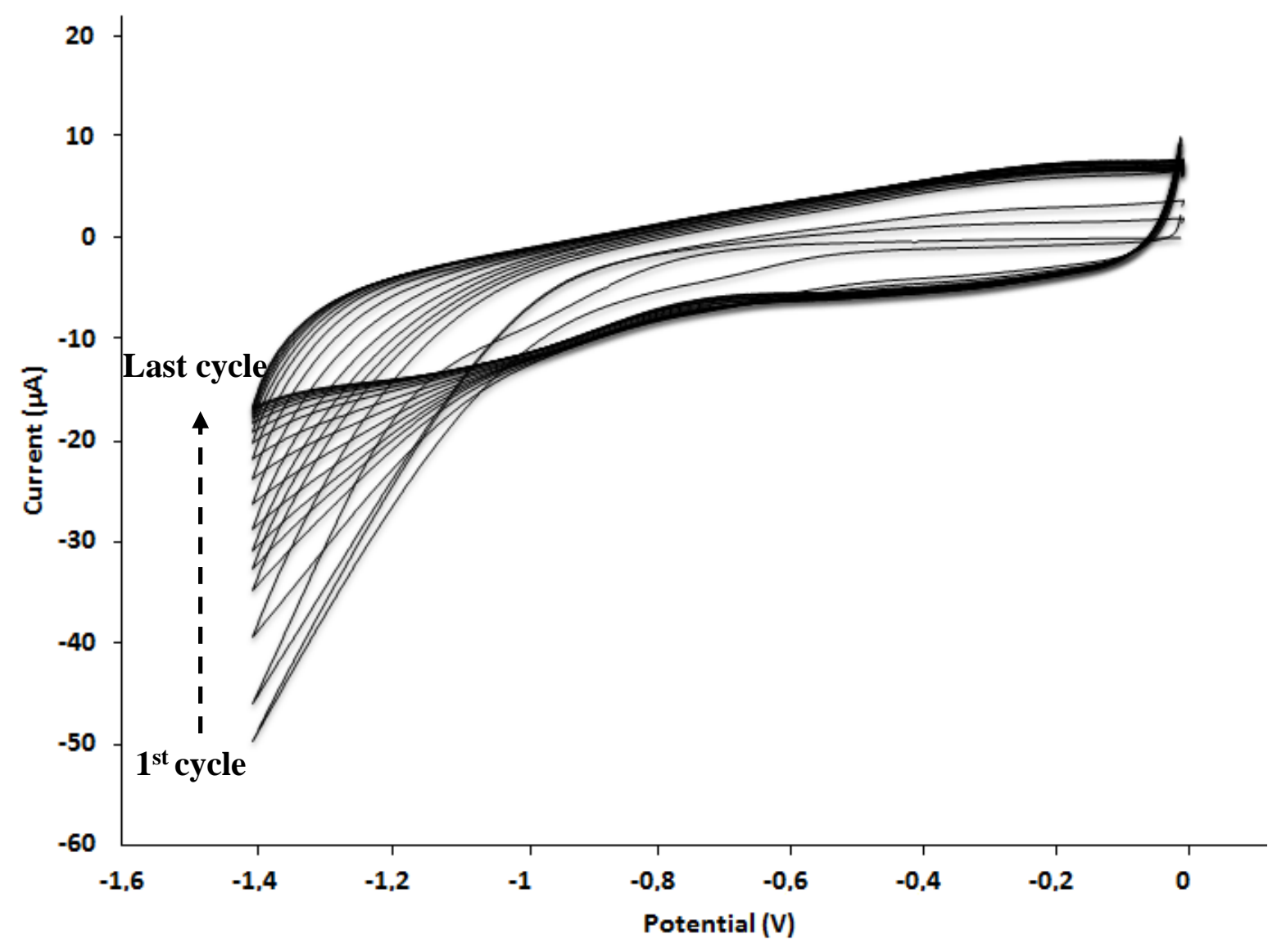

Figure 3. Preparation of ERGO with cyclic voltammetry of graphene oxide starting from 0 to $-1.4 \mathrm{~V}$ with a scan rate of $50 \mathrm{mV} / \mathrm{s}$.

To optimize the amperometric catechol response different $\%$ values of graphene oxide $(0.05-$ $1 \%$, Figure 4A), different thickness of ERGO (5-20 scans, Figure 4B), different volume of IrOxNPs (1-10 $\mu \mathrm{L}$, Figure 4C) and Tyr (2-10 $\mu \mathrm{L}$, Figure 4D) were studied. The best biosensing response towards $0.6 \mu \mathrm{M}$ catechol was detected when the biosensor was prepared using $0.1 \%$ GO. It was dropped onto the surface of SPE and 15 cycles CV were performed to obtain ERGO. Then the optimum volume of IrOxNPs were determined as $5 \mu \mathrm{L}$. Afterwards, 6 mM EDC and $10 \mathrm{mM}$ NHS was mixed with $5 \mu \mathrm{L}$ Tyr and dropped onto the surface of the screen printed electrode. Figure 4 shows the optimized condition for catechol detection. 

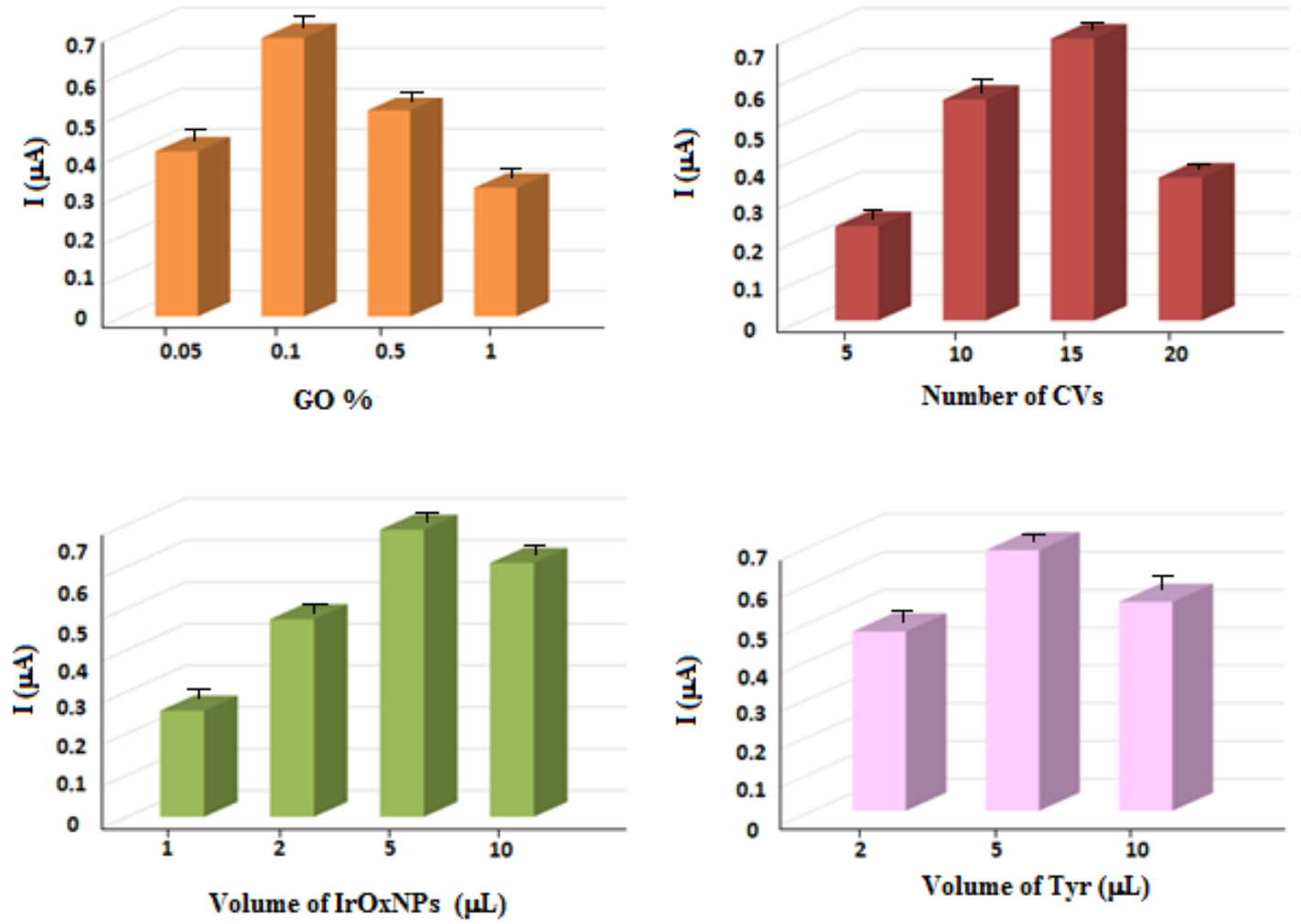

Figure 4. Optimization of A) Graphene oxide \% B) Number of CVs to obtain ERGO C)

Volume of IrOxNPs D) Volume of Tyr

Cyclic voltammograms of SPE/Tyr (curve b) SPE/ERGO/Tyr (curve c) and

$\mathrm{SPE} / \mathrm{ERGO} / \mathrm{IrOxNPs} / \mathrm{Tyr}$ (curve d) in the presence of $1 \mathrm{mM}$ catechol in $0.1 \mathrm{M}$ phosphate buffer at $\mathrm{pH} 6.5$ with $0.1 \mathrm{M} \mathrm{KCl}$ at $\mathrm{pH} 6.5$ were recorded (Figure 5). Cyclic voltammograms of phosphate buffer as blank on SPE (curve a) was also shown. Transformation of catechol to $o$-quinone within a two-electron process (one anodic and one cathodic peak) can be followed easily in these CVs (Papouchado et al., 1972; Papouchado et al., 1968; Rayn et al., 1980).

The designed SPE/ERGO/IrOxNPs/Tyr biosensor shows higher response toward catechol and the use of ERGO and IrOxNPs enhances the biosensing of catechol due to their high properties as can be seen from Figure 5 and 6.

Amperometric responses of SPE modified with Tyr, ERGO/Tyr, ERGO/IrOxNPs/Tyr for continuous additions of $0.2 \mu \mathrm{M}$ catechol while applying a $-200 \mathrm{mV}$ potential shows that the 
236 the biosensing one step further (Figure 6).

237

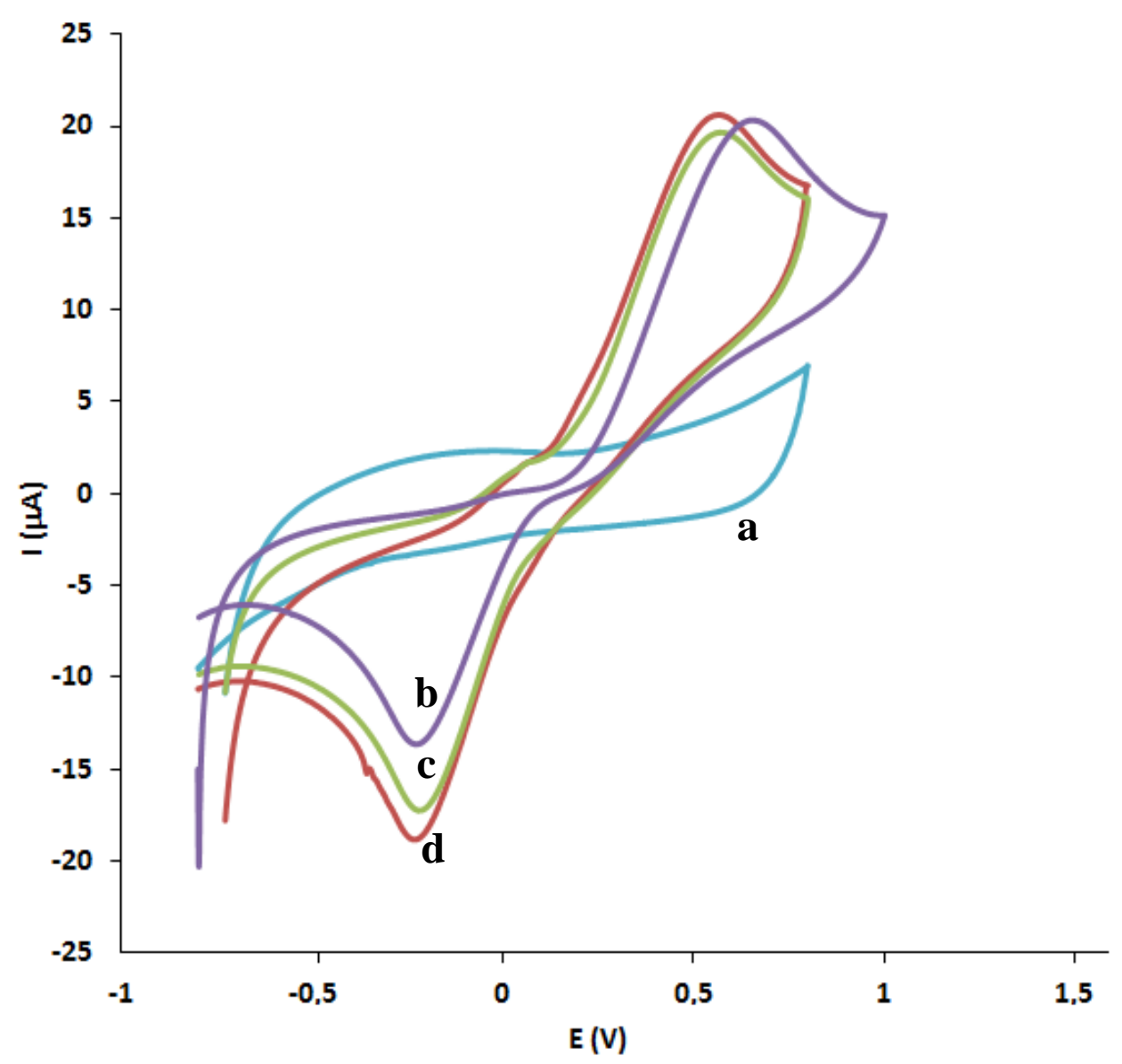

Figure 5. Cyclic voltammograms of a)

a) blank

b) SPE/Tyr

c) $\mathrm{SPE} / \mathrm{ERGO} / \mathrm{Tyr}$

d) 


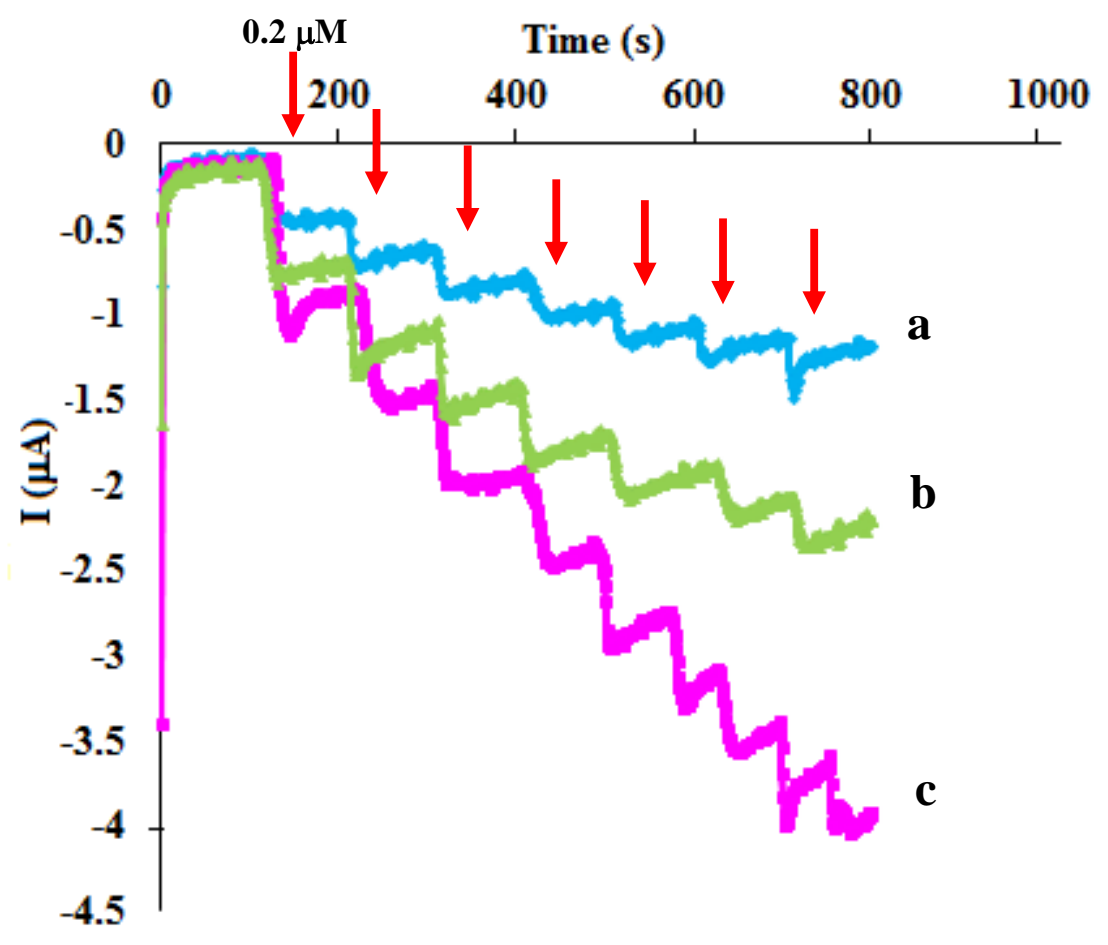

Figure 6. Current-time responses of a) SPE/Tyr, b)SPE/ERGO/Tyr and c)SPE/ERGO/IrOxNPs/Tyr for the successive addition of $0.2 \mu \mathrm{M}$ catechol solution, during stirring conditions within a working potential of $-0.2 \mathrm{~V}$ using $0.1 \mathrm{M}$ phosphate buffer at $\mathrm{pH}$ 6.5 with $0.1 \mathrm{M} \mathrm{KCl}$, at $300 \mathrm{rpm}$. .

The analytical characterization of the SPE/ERGO/IrOxNPs/Tyr biosensor was evaluated by continuous additions of catechol at different concentrations (Figure 7). A linear response for catechol with $\mathrm{r}=0.990 .2$ to $26 \mu \mathrm{M}$ was observed (Figure 7A). Within $25 \mathrm{~s}$ after each addition of catechol, sensitive bioelectrocatalytic response reaches about $95 \%$ of the steady-state current. Limit of detection (LOD) and limit of quantitation (LOQ) values of the developed biosensor were calculated according to the $3 \mathrm{~s} / \mathrm{m}$ and $10 \mathrm{~s} / \mathrm{m}$ criteria, respectively, where ' $\mathrm{s}$ ' is the standard deviation of the peak currents of low concentration of the analyte and ' $\mathrm{m}$ ' is the slope of the related calibration graph (Ermer 2005; Ozkan 2012; Uslu and Ozkan, 2011; Ozkan et al., 2015). LOD and LOQ values are also calculated as 0.053 and $0.161 \mu \mathrm{M}$ catechol, respectively, for catechol detection. In their work, Ozoner at al., developed a 
catechol biosensor using carbon nanotube modified polypyrrole (Ozoner et al., 2010). They came up with a biosensor, detecting catechol in the linear range between $3 \mu \mathrm{M}$ and $50 \mu \mathrm{M}$, with a detection limit of $0.671 \mu \mathrm{M}$ which is approximately 13 times higher than the LOD value $(0.053 \mu \mathrm{M})$ in the current work. In another work, by Tembe et al., catechol was detected between $6 \times 10^{-5}$ and $8 \times 10^{-4} \mathrm{M}$ with a detection limit of $6 \mu \mathrm{M}$ (Tembe et al., 2007). Zou et al., also developed a catechol biosensor using boron-doped nanocrystalline diamond film electrode. The biosensor showed a linear range between 5.0-120.0 $\mu \mathrm{M}$ which is approximately 25 times higher than our lowest concentration $(0.2 \mu \mathrm{M})$ in the linear range. In their work, Vicentini et al., used gold nanoparticles as the modifier and catechol detection was achieved in the linear range of $2.5 \times 10^{-6}$ to $9.5 \times 10^{-5} \mathrm{M}$ with LOD value of $1.7 \times 10^{-7} \mathrm{M}$ which is approximately 4 times higher than our LOD value (Vicentini et al., 2016). These results show advantages of the developed biosensor in in terms of analytical performance making it reliable enough to be used in inhibition-based detection of Captopril. For the complete validation of the designed biosensor, within-day repeatability measurements are also shown as the results of triplicate sets indicated by error bars in Figure 7B. Relative standard deviation (RSD) values were lower than $15 \%$ for between day repeatability and lower than $10 \%$ for within-day repeatability.
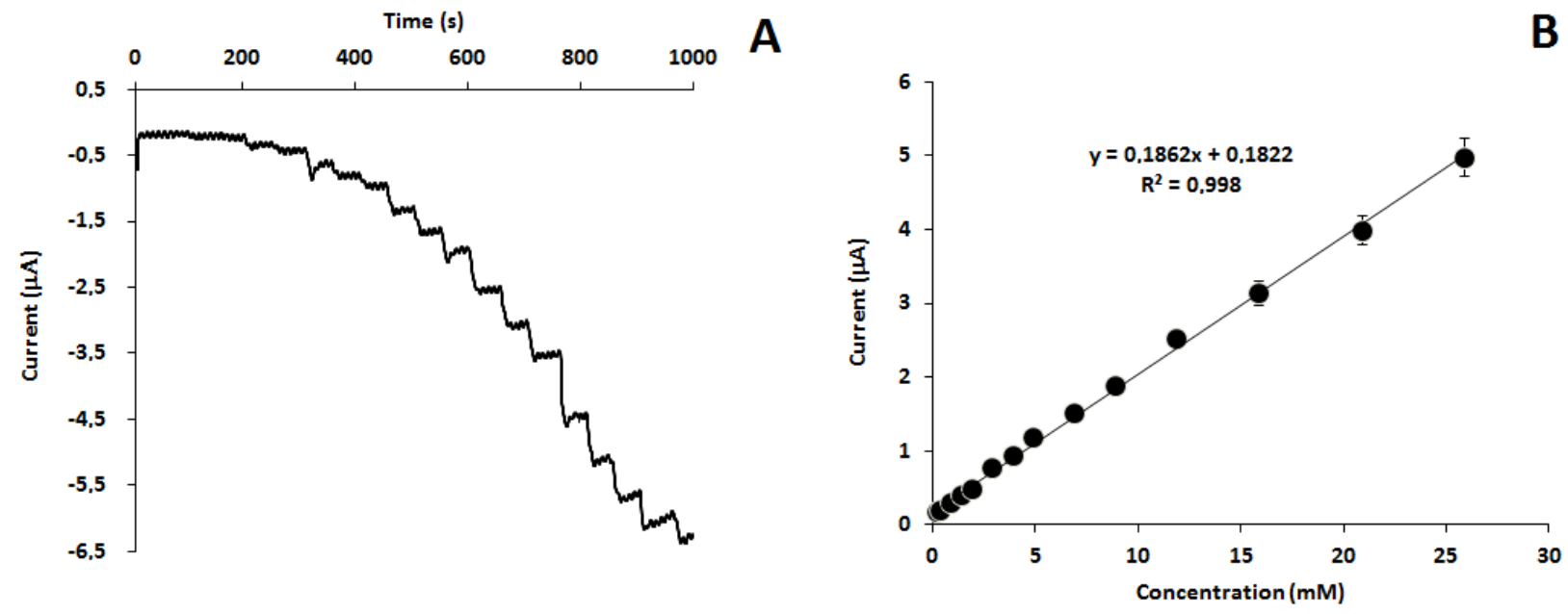
Figure 7. A) Typical current-time response curves for the successive additions of catechol to optimized SPE/ERGO/IrOxNPs/Tyr during stirring conditions within a working potential of $0.2 \mathrm{~V}$ using $0.1 \mathrm{M}$ phosphate buffer at $\mathrm{pH} 6.5$ with $0.1 \mathrm{M} \mathrm{KCl}$. B) Analytical calibration of the SPE/ERGO/IrOxNPs/Tyr biosensor as current versus catechol concentration

\subsection{Captopril detection and determination}

SPE/ERGO/IrOxNPs/Tyr biosensor was used to determine CAP through inhibition of Tyr, both chelating copper at the active site of tyrosinase and thioquinone formation pathways. Two strategies were performed and inhibition conditions were optimized. Figure 8 shows the change of the 'percentage of inhibition' (I \%) versus CAP concentration by thioquinone formation.

$\mathrm{I} \%$ is calculated as:

$$
I \%=\left(\left(I_{s s}-I_{p}\right) / I_{s s}\right) * 100
$$

where $I_{\text {ss }}$ current corresponds to the enzyme activity of the biosensor when the inhibitor (CAP) is not present. Lower steady state-currents $\left(\mathrm{I}_{\mathrm{p}}\right)$ refer to the catechol response after inhibition with CAP. By applying amperometric measurements, CAP was detected through inhibition of Tyr.

In the thioquinone formation pathway, it is well known that, CAP immediately reacts with $o$ quinones and forms thioquinone since $\mathrm{CAP}$ has $\mathrm{SH}$ units. Consequently the blocking of cycling between the o-quinone to catechol cannot occur (Raoof et al., 2012; Stone et al. 2003). Direct inhibition which is named as formation of thioquinone was linear from 0.05 to $14 \mu \mathrm{M}$ CAP with a correlation coefficient of 0.99. LOD and LOQ values were also calculated from $\mathrm{S} / \mathrm{N}$ ratio as, 0.008 and 0.025 respectively. 
For irreversible inhibition of Tyr by chelating copper at the active site of tyrosinase by CAP, since the inhibition is irreversible, a new biosensor was used for each point of the calibration. Moreover, this inhibition needs time; therefore incubation time was first optimized. For optimizing the incubation time, biosensing response for $1 \mu \mathrm{M}$ catechol is recorded. The same biosensor is incubated in $10 \mu \mathrm{M}$ CAP for different incubation times $(5,10,15$ and $20 \mathrm{~min})$. The optimum incubation time was found as $10 \mathrm{~min}$ with an inhibition percent of $38.49 \pm 1.82$ $\%$ inhibition for $1 \mu \mathrm{M}$ catechol. Under optimized inhibition conditions, a linear range between $0.1 \mu \mathrm{M}$ and $15 \mu \mathrm{M}$ CAP was obtained from the graph inhibition percentage as a function of CAP concentration (Figure 8). LOD and LOQ values were also calculated as 0.019 and 0.059 $\mu \mathrm{M}$ CAP, respectively.

For both pathways, RSD values for both in-day repeatability and between days repeatability are lower than $15 \%$. Analytical characterization of the inhibition pathways were performed and summarized in Table 1 including precision.

So far there is not any report on captopril detection through inhibition of tyrosinase but only studies related with electrochemical detection of captopril. In Table 2, recent studies related to captopril detection were summarized and compared with the results obtained in this work. 

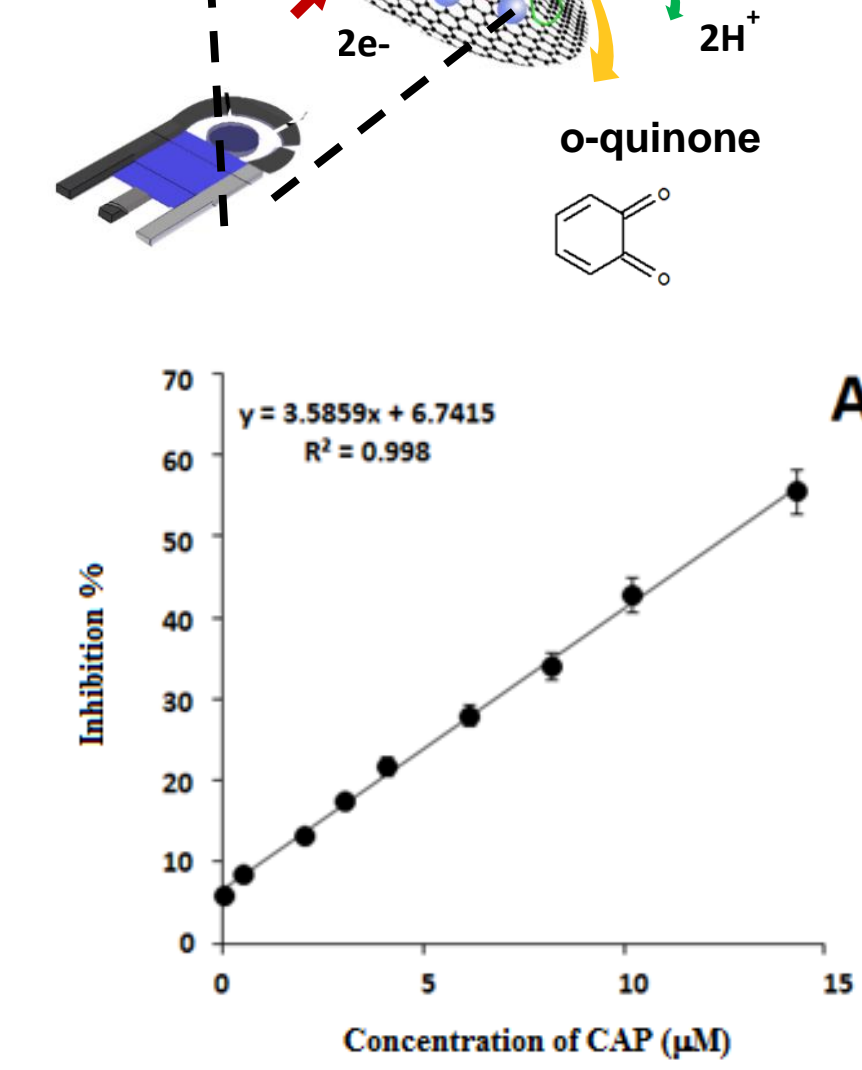<smiles>CCC(C)C1=C(O)C(O)CC1</smiles>

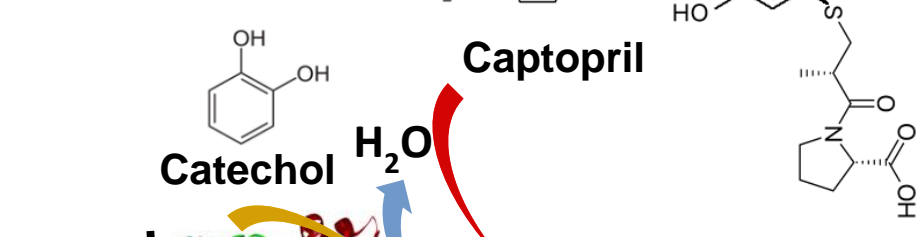

Thioquinone

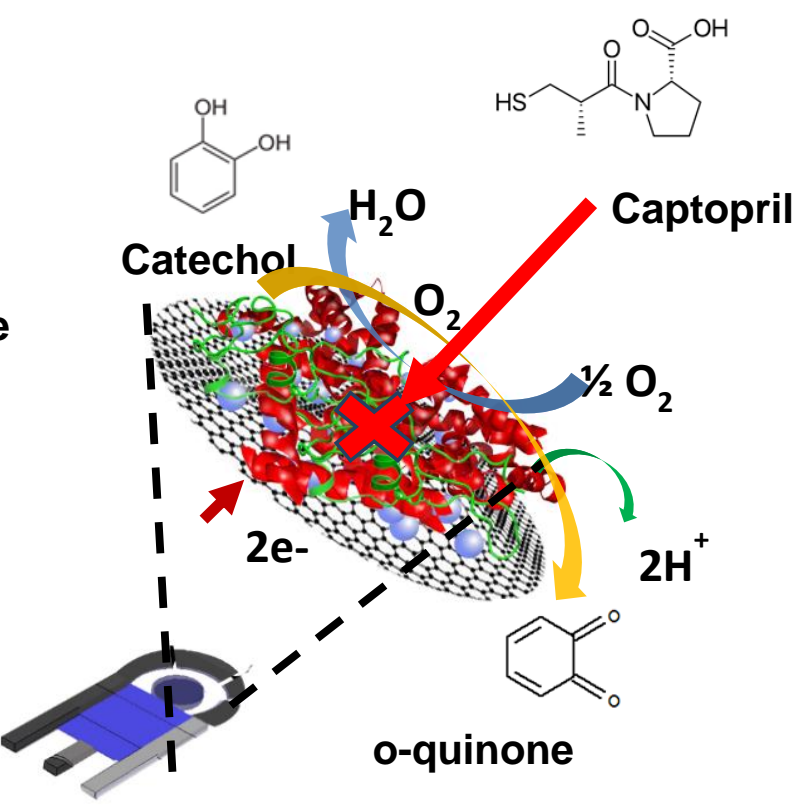

A

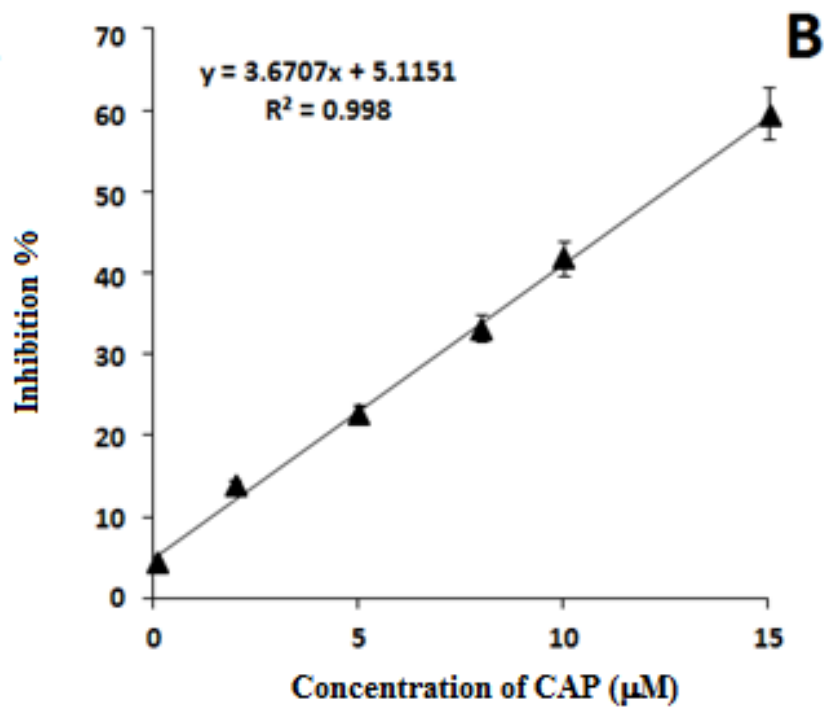

B

Figure 8 Calibration graph for Captopril detection through a) thioquinone formation b) 
Table 1. Regression data for both detection strategies of Captopril

338

Thioquinone formation

Chelating copper of $\mathbf{T y r}$

\begin{tabular}{|c|c|c|}
\hline Linearity range $(\mu \mathrm{M})$ & $0.05-14$ & $0.1-15$ \\
\hline Slope (Sensitivity, $\mathrm{I} \% \cdot \mu \mathrm{M}^{-1}$ ) & 3.59 & 3.67 \\
\hline Intercept & 6.74 & 5.12 \\
\hline Correlation coefficient & 0.99 & 0.99 \\
\hline Limit of Detection $(\mu \mathrm{M})$ & 0.008 & 0.019 \\
\hline Limit of Quantification $(\mu \mathrm{M})$ & 0.025 & 0.059 \\
\hline Within-day precision ${ }^{\mathrm{a}}(\mathrm{RSD} \%)$ & 2.73 & 6.72 \\
\hline Between-day precision $^{\mathrm{a}}$ (RSD & 3.89 & 7.93 \\
\hline
\end{tabular}


Table 2. Recent studies about determination of Captopril at the modified electrodes

\begin{tabular}{|c|c|c|c|c|c|c|}
\hline $\begin{array}{c}\text { Electrode } \\
\text { modification }\end{array}$ & Technique & Medium & $\begin{array}{c}\text { Potential } \\
(\mathrm{V})\end{array}$ & $\begin{array}{c}\text { LOD/LOQ } \\
(\mathrm{M})\end{array}$ & Sensitivity & Ref. \\
\hline $\begin{array}{c}\mathrm{N}-4,4^{\prime}- \\
\text { azodianilinefer } \\
\text { rocene/ } \\
\text { multiwall } \\
\text { carbon } \\
\text { nanotube } \\
\text { modified } \\
\text { carbon paste } \\
\text { electrode }\end{array}$ & $\begin{array}{c}\text { Differential } \\
\text { Pulse } \\
\text { Voltammetry }\end{array}$ & $\begin{array}{c}0.05 \mathrm{M} \\
\text { phosphate } \\
\text { buffer } \\
\text { (pH 7.0) }\end{array}$ & 0.55 & $3.0 \times 10^{-8}$ & $\begin{array}{c}0.01 \\
\left(\mu \mathrm{A} \cdot \mu \mathrm{M}^{-1}\right)\end{array}$ & $\begin{array}{c}\text { Taei et al. } \\
2015\end{array}$ \\
\hline $\begin{array}{c}\mathrm{ZnO}-\mathrm{CuO} \\
\text { Nanoplates/ } \\
\text { Modified } \\
\text { Carbon Paste } \\
\text { Electrode } \\
\end{array}$ & $\begin{array}{l}\text { Square Wave } \\
\text { Voltammetry }\end{array}$ & $\begin{array}{c}0.1 \mathrm{M} \\
\text { phosphate } \\
\text { buffer } \\
\text { (pH 7.0) }\end{array}$ & 0.28 & $9.0 \times 10^{-8}$ & $\begin{array}{c}0.03 \\
\left(\mu \mathrm{A} . \mu \mathrm{M}^{-1}\right)\end{array}$ & $\begin{array}{l}\text { Beitollahi } \\
\text { et al., } \\
2015\end{array}$ \\
\hline $\begin{array}{l}\text { 1,4-phenylene- } \\
\mathrm{N}, \mathrm{N}^{\prime} \text {-bis }(\mathrm{O}, \mathrm{O}- \\
\text { diphenylphora } \\
\text { midate)/CdS } \\
\text { quantum } \\
\text { dots/multi- } \\
\text { walled carbon } \\
\text { nanotubes } \\
\text { modified } \\
\text { glassy carbon } \\
\text { electrode }\end{array}$ & Amperometry & $\begin{array}{c}0.1 \mathrm{M} \\
\text { phosphate } \\
\text { buffer } \\
\text { (pH 9.0) }\end{array}$ & 0.32 & $15 \times 10^{-9}$ & $\begin{array}{c}0.28 \\
\left(\mu \mathrm{A} \cdot \mu \mathrm{M}^{-1}\right)\end{array}$ & $\begin{array}{c}\text { Paimard et } \\
\text { al., } 2015\end{array}$ \\
\hline $\begin{array}{c}\mathrm{CuO} \\
\text { nanoparticles/ } \\
\text { multi-wall } \\
\text { carbon } \\
\text { nanotube } \\
\text { nanocomposite } \\
\text { electrode }\end{array}$ & $\begin{array}{c}\text { Differential } \\
\text { Pulse } \\
\text { Voltammetry }\end{array}$ & $\begin{array}{c}0.02 \mathrm{M} \\
\text { Britton- } \\
\text { Robinson } \\
\text { buffer } \\
\text { (pH 2.3) }\end{array}$ & 0.50 & $3.0 \times 10^{-7}$ & $\begin{array}{c}0.0037 \\
\left(\mu \mathrm{A} . \mathrm{M}^{-1}\right)\end{array}$ & $\begin{array}{l}\text { Zargar et } \\
\text { al., } 2015\end{array}$ \\
\hline $\begin{array}{c}\mathrm{N}-(4- \\
\text { hydroxyphenyl } \\
\text { )-3,5- } \\
\text { dinitrobenzami } \\
\text { de modified } \\
\mathrm{ZnO/CNT} \\
\text { carbon paste } \\
\text { electrode }\end{array}$ & $\begin{array}{l}\text { Square Wave } \\
\text { Voltammetry }\end{array}$ & $\begin{array}{c}0.1 \mathrm{~mol} / \mathrm{L} \\
\text { phosphate } \\
\text { buffer } \\
(\mathrm{pH} \mathrm{6.0)} .\end{array}$ & 0.38 & $1.0 \times 10^{-8}$ & $\begin{array}{c}0.1014 \\
\left(\mu \mathrm{A} \cdot \mu \mathrm{M}^{-1}\right)\end{array}$ & $\begin{array}{c}\text { Bagheri et } \\
\text { al., } 2014\end{array}$ \\
\hline $\begin{array}{c}\text { NiO NPs } \\
\text { modified } \\
\text { (9,10-dihydro- } \\
9,10- \\
\text { ethanoanthrace }\end{array}$ & $\begin{array}{l}\text { Square Wave } \\
\text { Voltammetry }\end{array}$ & $\begin{array}{c}0.1 \mathrm{~mol} / \mathrm{L} \\
\text { phosphate } \\
\text { buffer } \\
(\mathrm{pH} \mathrm{6.0)} .\end{array}$ & 0.31 & $7.0 \times 10^{-3}$ & $\begin{array}{c}0.063 \\
\left(\mu \mathrm{A} \cdot \mu \mathrm{M}^{-1}\right)\end{array}$ & $\begin{array}{l}\text { Karimi- } \\
\text { Maleh et } \\
\text { al., } 2014\end{array}$ \\
\hline
\end{tabular}
ne-11,12- 


\begin{tabular}{|c|c|c|c|c|c|c|}
\hline $\begin{array}{c}\text { dicarboximido) } \\
\text {-4-ethyl } \\
\text { benzene-1,2- } \\
\text { diol carbon } \\
\text { paste electrode }\end{array}$ & & & & & & \\
\hline $\begin{array}{c}\text { Vinyl } \\
\text { ferrocene } \\
\text { modified } \\
\text { carbon } \\
\text { nanotubes } \\
\text { paste electrode }\end{array}$ & $\begin{array}{l}\text { Square Wave } \\
\text { Voltammetry }\end{array}$ & $\begin{array}{c}0.1 \mathrm{M} \\
\text { phosphate } \\
\text { buffer } \\
\text { solution } \\
\text { (pH 8.0) }\end{array}$ & 0.43 & $8.0 \times 10^{-5}$ & $\begin{array}{c}0.1091 \\
\left(\mu \mathrm{A} \cdot \mu \mathrm{M}^{-1}\right)\end{array}$ & $\begin{array}{l}\text { Ensafi et } \\
\text { al., } 2012\end{array}$ \\
\hline $\begin{array}{l}\text { SPE/ERGO/ } \\
\text { IrOxNPs/Tyr }\end{array}$ & Amperometry & $\begin{array}{c}0.1 \mathrm{M} \\
\text { phosphate } \\
\text { buffer } \\
(\mathrm{pH} 6.5)\end{array}$ & 0.20 & $8.0 \times 10^{-9}$ & $\begin{array}{c}3.6 \\
\left(\mathrm{I} \% . \mu \mathrm{M}^{-1}\right)\end{array}$ & This work \\
\hline
\end{tabular}




\subsection{Application to real samples}

In order to prove the applicability of developed CAP detection strategies, detection in real samples also were performed. CAP was analyzed first in a pharmaceutical dosage form known as Kaptopril ${ }^{\circledR}$. The obtained acceptable level is shown in table 3. Moreover, by utilizing recovery studies both in pharmaceutical and human serum analyzes applicability of the proposed method also was confirmed.

Table 3. Detection of CAP from spiked human serum and pharmaceutical dosage form Kaptoril $^{\circledR}$

\section{Thioquinone formation}

\begin{tabular}{|c|c|c|c|c|}
\hline & Kaptopril $^{\circledR}$ & Human serum & Kaptopril $^{\circledR}$ & Human serum \\
\hline Label Claimed (mg) & 25.00 & - & 25.00 & - \\
\hline Found (mg) & 24.85 & - & 25.10 & - \\
\hline RSD \% & 6.94 & - & 9.77 & - \\
\hline Bias \% & 0.58 & - & -0.40 & - \\
\hline Added $(\mu \mathrm{M})$ & 2.00 & 10.00 & 2.00 & 10.00 \\
\hline Found $(\mu \mathrm{M})$ & 2.03 & 10.19 & 2.04 & 10.76 \\
\hline Recovery (\%) & 101.46 & 101.85 & 102.11 & 107.63 \\
\hline RSD \% & 7.35 & 5.56 & 5.87 & 7.30 \\
\hline Bias \% & -1.46 & -1.85 & -2.11 & -7.63 \\
\hline
\end{tabular}

Chelating copper of $\mathbf{T y r}$

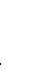


In tyrosinase-based electrochemical biosensor, since the working potential is low $(-0.2 \mathrm{~V}$ or less), more selective biosensors can be obtained compared to acetylcholinesterase and free mediators-based ones that work at $0.6 \mathrm{~V}$. The effect of the interfering species and other electroactive compounds is low in tyrosinase-based electrochemical biosensor. To show that the system is not affected by possible interferences such as ascorbic acid, uric acid and paracetamol interference studies were also performed. Successive addition of $15 \mu \mathrm{M}$ ascorbic acid, uric acid and paracetamol were achieved with following addition of $15 \mu \mathrm{M}$ catechol solution. As shown in figure 9 the catechol biosensing is not affected by these potential interfering compounds.

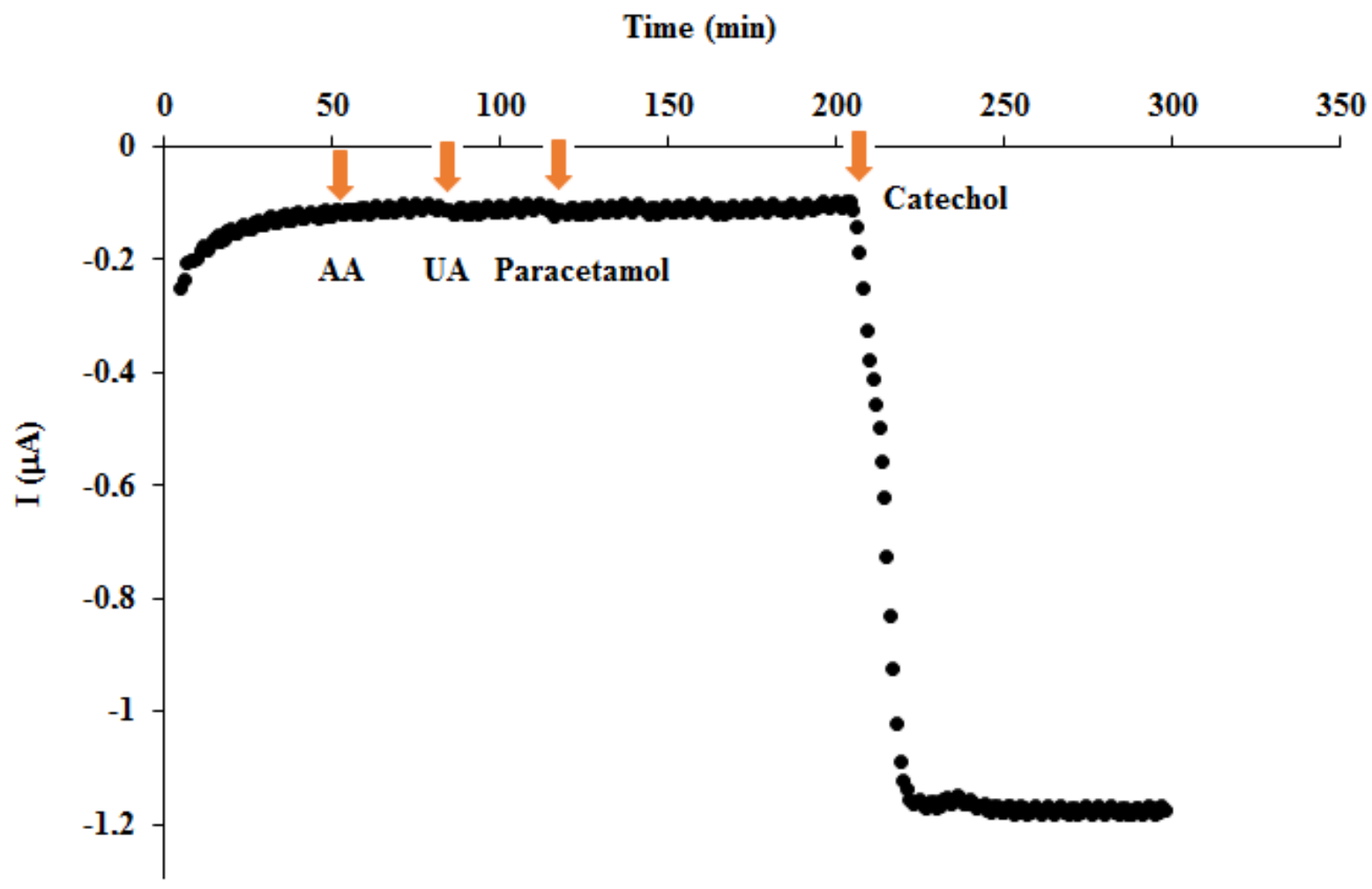

Figure 9. Interference studies for SPE/ERGO/IrOxNPs/Tyr biosensor upon successive additions of $15 \mu \mathrm{M}$ of paracetamol, ascorbic acid, uric acid and $15 \mu \mathrm{M}$ of catechol in stirring conditions at an working potential of $-0.2 \mathrm{~V}$ using $0.1 \mathrm{M}$ phosphate buffer at $\mathrm{pH} 6.5$ with 0.1 $\mathrm{M} \mathrm{KCl}$. 


\section{CONCLUSIONS}

In conclusion of this study we have shown a novel biosensor that contains tyrosinase which activity is inhibited by angiotensin-converting enzyme inhibitor drug. The biosensor is built using screen printed electrode as transducer that was first modified with electrochemically reduced graphene followed by IrOxNPs. Tyr immobilization was achieved using EDC/NHS coupling reagents. All the parameters effecting the catechol biosensing were optimized. Under optimized conditions, the designed biosensor was analytically characterized regarding catechol followed by CAP detection studies. CAP was detected through two ways: chelating copper at the active site of tyrosinase and thioquinone formation. Analytical performances of both strategies in terms of precision, accuracy, standard error of slope and intercept as well as LOD and LOQ were calculated. In thioquinone formation pathway, the biosensor gives a linear response from 0.05 to $14 \mu \mathrm{M}$ with LOD value of $0.008 \mu \mathrm{M}$ CAP. For the pathway chelating copper at the active site of tyrosinase, inhibition conditions were optimized and CAP was detected through inhibition, between $0.1 \mu \mathrm{M}$ and $15 \mu \mathrm{M}$ CAP with a LOD value of $0.019 \mu \mathrm{M}$ CAP. The fully validated inhibition methods were successfully applied to real samples of pharmaceutical dosage form called Kaptopril ${ }^{\circledR}$ and spiked human serum from male AB plasma samples. These novel CAP detection strategies, using SPE/ERGO/IrOxNPs/Tyr biosensor, can encourage other studies with interest for electrochemical detection of drugs through inhibition of Tyr or other enzymes.

\section{Acknowledgement}

S. Kurbanoglu acknowledges the support given by Ankara University BAP 14L0237002 for her $\mathrm{PhD}$ thesis project. Nanobiosensors and Bioelectronics Group acknowledges the support from MINECO (project MAT2014-52485-P and Severo Ochoa Program, Grant SEV-20130295) and Secretaria d'Universitats i Recerca del Departament d'Economia i Coneixement de la Generalitat de Catalunya (2014 SGR 260). 


\section{REFERENCES}

Andujar-Sanchez, M.; Cámara-Artigas, A.; Jara-Pérez, V. 2004. Biophys. Chem., 111, 183189.

Atkinson, A. B.; Robertson, J. I. S. 1979. The Lancet, 314, 836-839.

Baptista-Pires, L.; Pérez-López, B.; Mayorga-Martinez, C.C.; Morales-Narváez E.;, Domingo, N.; Esplandiu, M. J.; Alzina, F.; Sotomayor Torres C.M.; Merkoçi, A. 2014. Biosens Bioelectron, 61, 655-662

Bagheri, H.; Karimi-Maleh, H.; Karimi, F.; Mallakpour, S.; Keyvanfard, M. 2014. J. Mol Liq, 198, 193-199.

Beitollahi, H., Ghofrani Ivari, S., Alizadeh, R., Hosseinzadeh, R. 2015. Electroanalysis, 27, 1742-1749.

Chu, H. L.; Wang, B. S.; Chang, L. C.; Chang, L. W.; Duh, P. D. 2012. J Food Drug Anal, 20 3.

Cleland, J. G.; Dargie, H. J.; Hodsman, G. P.; Ball, S. G.; Robertson, J. I.; Morton, J. J.; Gillen, G. 1984. Brit. Heart J., 52, 530-535.

Conde, J., Ambrosone, A., Sanz, V., Hernandez, Y., Marchesano, V., Tian, F.; Child, H.; Berry, C.C.; Ibarra, M.R.; Baptista, P.V.; Tortiglione, C.; de la Fuente. J.M. 2012. ACS Nano, $6,8316-8324$.

Conde, J.; Baptista, P. V.; Hernández, Y.; Sanz, V.; De La Fuente, J. M. 2012. Nanomedicine, 7, 1657-1666.

Davies, T. J.; Hyde, M. E.; Compton, R. G. 2005. Angew Chem, 117, 5251-5256.

Dong, X. C.; Huang, W.; Chen, P. 2011. Nanoscale Res Lett, 6, 60-66.

Ehlers, M. R.; Riordan, J. F. 1989. Biochemistry, 28, 5311-5318.

Ensafi, A. A.; Monsef, M.; Rezaei, B.; Karimi-Maleh, H. 2012. Anal Meth, 4(5), 1332-1338. 
Ermer, J.; Miller J. H. McB. (Eds), 2005. Method Validation in Pharmaceutical Analysis, Wiley VCH Publishers, Weinheim.

Espin, J. C.; Wichers, H. J. 2001. BBA -Protein Struct M, 1544, 289-300.

Espin, J. C.; Morales, M.; Varon, R.; Tudela, J.; Garciacanovas, F. 1995. Anal Biochem, 231, 237-246.

Farid, M. M.; Goudini, L.; Piri, F.; Zamani, A.; Saadati, F. 2016. Food Chem, 194, 61-67.

Gan, T.; Hu, S. 2011 Microchim Acta, 175, 1-19.

Garg, B.; Bisht, T.; Ling, Y. C. 2015. Molecules, 20, 14155-14190.

Gómez-Navarro, C.; Weitz, R. T.; Bittner, A. M.; Scolari, M.; Mews, A.; Burghard, M.; Kern, K. 2007 Nano Lett, 7, 3499-3503.

Guo, J.; Yang, Y.; Hu, X.; Li, Y. 2015. Science China Chem, 58, 885-891.

Han, H. S.; Seol, H.; Kang, D. H.; Ahmed, M. S.; You, J. M.; Jeon, S. 2014. Sensor Actuat B: Chem, 204, 289-296.

Huang, T.; He, Z.; Yang, B.; Shao, L.; Zheng, X.; Duan, G. 2006. J Pharmaceut Biomed, 41, 644-648.

Karimi-Maleh, H.; Moazampour, M.; Gupta, V. K.; Sanati, A. L. 2014. Sens Actuat B: Chem, $199,47-53$.

Kim, Y. J.; Uyama, H. 2005. Cell Mol Life Sci, 62, 1707-1723.

Kumar, S.; Ahlawat, W.; Kumar, R.; Dilbaghi, N. 2015. Biosens Bioelectron, 70, 498-503.

Kurbanoglu, S.; Mayorga-Martinez, C. C.; Medina-Sánchez, M.; Rivas, L.; Ozkan, S. A.; Merkoçi, A. 2015. Biosens Bioelectron, 67, 670-676.

Kuwabara, T.; Tomita, E.; Sakita, S.; Hasegawa, D.; Sone, K.; Yagi, M. 2008. J Phys Chem C, 112, 3774-3779.

Li, B.; Pan, G.; Avent, N. D.; Lowry, R. B.; Madgett, T. E.; Waines, P. L. 2015. Biosens Bioelectron, 72, 313-319. 
Liu, X.; Li, Y.; Song, Z. 2015. Instrum Sci Technol, 43, 197-213.

Mayorga-Martinez, C. C.; Madrid, R. E.; Felice, C. J. 2008. Sens Actuat B: Chem, 133, 682686.

Mayorga-Martinez, C. C., Pino, F., Kurbanoglu, S., Rivas, L., Ozkan, S. A., Merkoçi, A. 2014. J Mat Chem B, 2(16), 2233-2239.

McAreavey, D.; Robertson, J. I. S. 1999. Drugs, 40, 326-345.

Naish-Byfield, S.; Cooksey, C. J.; Riley, P. A. 1994. Biochem J, 304, 155-162.

Novoselov, K. S.; Geim, A. K.; Morozov, S. V.; Jiang, D.; Zhang, Y.; Dubonos, S. A.;

Grigorieva I.V.;. Firsov, A. A. 2004. Science, 306, 666-669.

Okot-Kotber, M.; Liavoga, A.; Yong, K. J.; Bagorogoza, K. 2002. J Agr Food Chem, 50, 2410-2417.

Ozoner, S. K.; Yalvac, M.; Erhan, E. 2010. Curr Appl Physics, 10(1), 323-328.

Ozkan, S. A. 2012. Electroanalytical methods in pharmaceutical analysis and their validation. HNB publishing, New York.

Ozkan, S.A.; Kauffmann, J.M.; Zuman, P. 2015. Electroanalysis in Biomedical and Pharmaceutical Sciences, Springer-Verlag Berlin Heidelberg.

Paimard, G., Gholivand, M. B., Shamsipur, M., Gholivand, K., Mohammadi-Behzad, L., Gholami, A., Barati, A. 2015. J Electroanal Chem, 738, 176-183.

Papouchado, L.; Petrie, G.; Adams, R. N. 1972. J. Electroanal. Chem Interfac Electrochem., $38,389-395$.

Papouchado, L.; Petrie, G.; Sharp, J. H.; Adams, R. N. 1968. J Am Chem Soc, 90, 5620-5621. Patchett, A. A.; Harris, E.; Tristram, E. W.; Wyvratt, M. J., Wu, M. T.; Taub, D.; Peterson E.R.; Ikeler T.J.; Ten Broeke J.; Payne L.G .; Ondeyka, D.L.; Thorsett E.D.; Greenlee W.J.; Lohr N.S.; Hoffsommer R.D.; Joshua H.; Ruyle W.V.; Rothrock J.W.; Aster S.D.; Maycock 
A.L.; Robinson F.M.; Hirschmann R.; Sweet C.S.; Ulm E.H.; Gross D.M.; Vassil T.C.; Stone C.A. 1980. Nature, 288, 280-283.

Piepho, R. W. 2000. Am J Health-Syst Ph, 57, 3-7.

Rabti, A.; Mayorga-Martinez, C. C.; Baptista-Pires, L.; Raouafi, N.; Merkoçi, A.; 2016. Anal Chim Acta, In Press.

Raoof, J. B., Ojani, R., Amiri-Aref, M., Chekin, F. 2012. Russ J Electrochem, 48, 450-456.

Reza, K. K.; Ali, M. A.; Srivastava, S.; Agrawal, V. V.; Biradar, A. M. 2015. Biosens Bioelectron, 74, 644-651.

Rivas, L., de la Escosura-Muñiz, A., Pons, J., Merkoçi, A. 2014. Electroanalysis, 26(6), 1287 1294.

Ryan, M. D., Yueh, A., Chen, W. Y. 1980. J Electrochem Soc, 127, 1489-1495.

Sanz, V.; Conde, J.; Hernández, Y.; Baptista, P. V.; Ibarra, M. R.; Jesús, M. 2012. J Nanoparticle Res, 14, 1-9.

Shao, Y.; Wang, J.; Wu, H.; Liu, J.; Aksay, I. A.; Lin, Y. 2010. Electroanalysis, 22, 10271036.

Smith, C. G.; Vane, J. R. 2003. The FASEB Journal, 17, 788-789.

Song, J. C.; White, C. M. 2002. Clin pharmacokinet, 41, 207-224.

Stefan, R. I.; Van Staden, J. K. F.; Aboul-Enein, H. Y. 2000. Biosens Bioelectron, 15(1), 1-5.

Stone, C. G., Cardosi, M. F., Davis, J. 2003. Anal Chim Acta, 491, 203-210.

Tembe, S.; Inamdar, S.; Haram, S.; Karve, M.; D'Souza, S. F. 2007. J Biotech, 128(1), 80-85.

Taei, M., Hasanpour, F., Zahedi, G. 2015. B Chemi Soc Ethiopia, 29, 149-156.

Tolosa, V. M.; Wassum, K. M.; Maidment, N. T.; Monbouquette, H. G. 2013. Biosens Bioelectron, 42, 256-260.

Uslu, B.; Ozkan, S. A. 2011. Anal Lett, 44(16), 2644-2702.

Vamos-Vigyazo, L.; Haard, N. F. 1981. Crit Rev Food Sci, 15, 49-127. 
496 Yang, L.; Liu, D.; Huang, J.; You, T. 2014. Sens Actuat B: Chem, 193, 166-172.

497 Yun, M.; Choe, J. E.; You, J. M.; Ahmed, M. S.; Lee, K.; Üstündağ, Z., Jeon, S. 2015. Food 498 Chem, 169, 114-119.

499 Zargar, B.; Parham, H.; Hatamie, A. 2015. Anal Meth, 7, 1026-1035.

500 Zhang, S. B.;Yan, Y. T.; Huo, Y. Q.; Yang, Y.; Feng, J. L.; Chen, Y. F. 2014. Mater Chem 501 Phys, 148, 903-908.

502 Zhang, X.; Zhang, B.; Huang, D.; Yuan, H., Wang, M.; Shen, Y. 2014. Carbon, 80, 591-598.

503

Zhao, J.; Pei, S.; Ren, W.; Gao, L.; Cheng, H. M. 2010. Acs Nano, 4, 5245-5252.

504 
Figure and Table Captions

Figure 1. SEM images of (A) ERGO and IrOx (B), ERGO/IrOxNPs/Tyr Scale bars of SEM images are $200 \mathrm{~nm}$. The SEM images were obtained using backscatter electrons mode.

Figure 2. Schematic representation of proposed detection system

Figure 3. Preparation of ERGO with cyclic voltammetry of graphene oxide starting from 0 to $-1.4 \mathrm{~V}$ with a scan rate of $50 \mathrm{mV} / \mathrm{s}$.

Figure 4. Optimization of A) Graphene oxide \% B) Number of CVs to obtain ERGO C) Volume of IrOxNPs D) Volume of Tyr

Figure 5. Cyclic voltammograms of

a) blank

b) SPE/Tyr

c) SPE/ERGO/Tyr SPE/ERGO/IrOxNPs/Tyr in the presence of $1 \mathrm{mM}$ catechol in $0.1 \mathrm{M}$ phosphate buffer at $\mathrm{pH}$ 6.5 with $0.1 \mathrm{M} \mathrm{KCl}$.

Figure

6. Current-time responses of

a) SPE/Tyr,

b) SPE/ERGO/Tyr and stirring conditions within a working potential of $-0.2 \mathrm{~V}$ using $0.1 \mathrm{M}$ phosphate buffer at $\mathrm{pH}$ 6.5 with $0.1 \mathrm{M} \mathrm{KCl}$, at $300 \mathrm{rpm}$.

Figure 7. A) Typical current-time response curves for the successive additions of catechol to optimized SPE/ERGO/IrOxNPs/Tyr biosensor in in $0.1 \mathrm{M}$ phosphate buffer with $0.1 \mathrm{M} \mathrm{KCl}$ at $\mathrm{pH}$ 6.5. B) Analytical calibration of the SPE/ERGO/IrOxNPs/Tyr biosensor as current versus catechol concentration

Figure 8 Calibration graph for Captopril detection through a) thioquinone formation b) chelating copper at the active site of tyrosinase

Figure 9. Interference studies for $\mathrm{SPE} / \mathrm{ERGO/IrOxNPs/Tyr}$ biosensor upon successive additions of $15 \mu \mathrm{M}$ of paracetamol, ascorbic acid, uric acid and $15 \mu \mathrm{M}$ of catechol in during 
529 stirring conditions within a working potential of $-0.2 \mathrm{~V}$ using $0.1 \mathrm{M}$ phosphate buffer at $\mathrm{pH}$ 6.5 with $0.1 \mathrm{M} \mathrm{KCl}$.

531 Table 1. Regression data for both detection strategies of Captopril

532 Table 2. Recent studies about determination of Captopril at the modified electrodes

533 Table 3. Detection of Captopril from spiked human serum and pharmaceutical dosage form 534 Kaptoril $^{\circledR}$ 